\title{
Operasi caesar kasus distokia pada kuda miniature
}

\author{
Amrozi $^{1 *}$, R.H. Soehartono ${ }^{1}$, E.R. Adistya ${ }^{2}$, I Mahardi ${ }^{3}$, H. Mukarromah ${ }^{3}$, M.I. Satria ${ }^{3}$, B. Ach- \\ madi $^{1}$, Azery bin Kamiring ${ }^{2}$, Afiqah binti Abd Latif ${ }^{2}$
}

${ }^{1}$ Departemen Klinik Reproduksi dan Patologi, Fakultas Kedokteran Hewan, Institut Pertanian Bogor, Bogor

${ }^{2}$ Rumah Sakit Hewan Pendidikan, Fakultas Kedokteran Hewan, Institut Pertanian Bogor, Bogor

${ }^{3}$ Dr Am Veterinary Services, J1 Ketimun C93, Sinarsari, Dramaga, Bogor

\begin{abstract}
ABSTRAK: Distokia adalah kesulitan kelahiran yang dapat menyebabkan trauma pada induk kuda, memerlukan bantuan kelahiran dan mengurangi viabilitas neonatal. Distokia terjadi ketika terdapat kegagalan dalam satu atau lebih dari tiga komponen utama proses kelahiran, yaitu kekuatan mendorong, kecukupan jalan kelahiran, dan ukuran dan posisi fetus. Seekor kuda miniature telah mengalami distokia yang disebabkan oleh ukuran fetus lebih besar dari ukuran pelvis induk. Reposisi dan penarikan manual telah dilakukan dan tidak berhasil mengeluarkan fetus. Penanganan operasi caesar dengan anestesi general dilakukan untuk menyelamatkan induk kuda. Kuda mulai makan dan minum secara normal serta menunjukkan respon yang baik pasca operasi caesar.
\end{abstract}

\section{Kata kunci:}

caesar, distokia, kuda miniature

\section{- PENDAHULUAN}

Distokia yang terjadi pada kuda dapat menyebabkan trauma pada induk dan mengurangi daya tahan anak yang dilahirkan, bahkan dapat menyebabkan kematian induk dan anak (Purohit \& Honnappagol 2009). Distokia terjadi ketika terdapat kegagalan dalam satu atau lebih dari tiga komponen utama proses kelahiran, yaitu kemampuan perejanan induk, saluran kelahiran sempit, dan ukuran serta posisi fetus (Noakes et al. 2001). Penanganan distokia dapat dilakukan dengan reposisi, traksi, rotasi fetus, fetotomi fetus yang mati atau operasi sesar untuk penyelamatan induk dan anak. Akan tetapi, teknik operasi caesar pada kuda miniature belum banyak dilaporkan. Tulisan ini menjelaskan teknik penanganan kasus distokia pada kuda miniature dengan metode operasi caesar di Rumah Sakit Hewan Pendidikan, FKH IPB. Operasi caesar harus dilakukan karena fetus yang besar dan saluran kelahiran sempit sehingga tidak mungkin dilakukan penarikan fetus (Schultz et al. 2008).

\section{- KASUS}

Sinyalemen: Seekor kuda miniature telah dibawa Rumah Sakit Hewan Pendidikan FKH IPB, umur 3 tahun, betina bunting primipara. Status presen: Denyut jantung cepat dan pernafasan dangkal dan cepat, berkeringat banyak, suhu normal dan masih ada nafsu makan minum. Pemeriksaan klinis: Kelamin luar bengkak melebar dan terdapat leleran cairan berdarah. Kontraksi otot perut dan kejang kejang pada kaki belakang. Inspeksi dan palpasi per vaginal ditemukan fetus posisi normal (longitudinal dorsosacral anterior), ukuran lebih besar dari saluran kelahiran dan tidak berespon terhadap rangsangan. Diagnosa: distokia karena fetus terlalu besar dan telah mati (Moges 2016). Terapi: Operasi caesar untuk menyelamatkan induk kuda (Gambar 1).

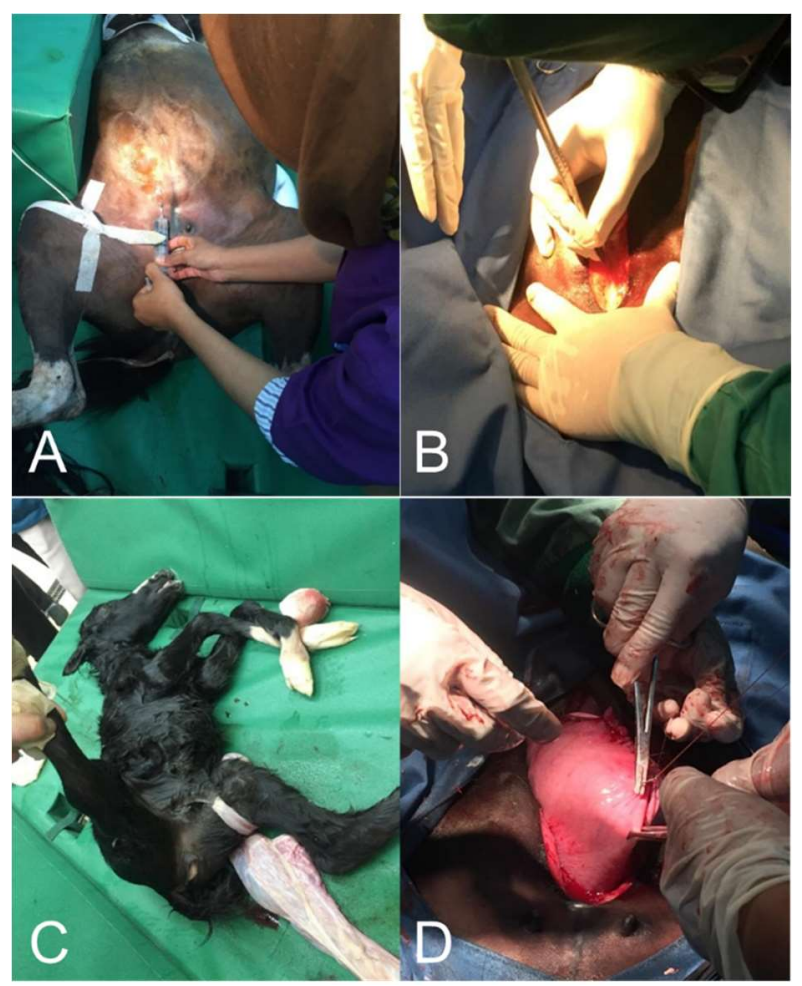

Gambar 1. Operasi caesar penanganan kasus distokia pada kuda miniature. (A) anestesi lokal, (B) penyayatan kulit, otot, (C) fetus mati telah dikeluarkan (D) penjahitan uterus.

Diterima: 11-05-2020 | Direvisi: 17-06-2020 | Disetujui: 21-06-2020

(C) 2020 CC-BY-SA. Ini adalah artikel Open Access yang didistribusikan berdasarkan ketentuan dari Creative Commons Attribution ShareAlike 4.0 International License (https://creativecommons.org/licenses/by-sa/4.0/). 


\section{- HASIL DAN PEMBAHASAN}

Distokia pada kuda ras miniature terjadi karena fetopelvic disparity yaitu ukuran pelvis mare relatif lebih kecil dibanding ukuran fetus yang besar (Schultz et al. 2008). Kasus distokia dalam tulisan ini keadaan induk dalam kondisi terbaring lemah akibat kelelahan merejan dan mengalami dehidrasi. Infus ringer laktat diberikan untuk mencegah syok hipovolemik selama masa operasi caesar. Kuda diberikan anastesi xylazine (Thiazine $100 ® 100 \mathrm{mg} / \mathrm{mL}$ ) $1 \mathrm{ml}$ secara i.v. dan ketamin (Ketamil $\left.{ }^{\circledR} 100 \mathrm{mg} / \mathrm{mL}\right) 2 \mathrm{ml}$ secara i.v. Isofluran digunakan sebagai pemelihara anestesi selama operasi caesar berlangsung. Pendekatan operasi midline dilakukan dengan pertimbangan ukuran fetus besar dan pendarahan minimal (Abubakar et al. 2014). Rambut daerah sayatan dicukur dibagian linea alba, disinfeksi menggunakan alkohol $70 \%$ dan povidone iodine. Anastesi lokal menggunakan $5 \mathrm{ml}$ lidocaine $2 \%$ di daerah perifer linea alba secara sub kutan (Gambar 1A).

Insisi dilakukan secara posterior dari umbilical cord di daerah linea alba sampai mendekati ambing (Gambar 1B). Setelah rongga abdomen dibuka, eksplorasi bagian abdomen dan untuk mendapatkan cornua uteri. Fetus dikeluarkan melalui sayatan uterus sesuai proporsi ukuran fetus (Gambar 1C) dan penjahitan pada sayatan insisi yang dilakukan pada dinding uterus menggunakan material benang Vicryl $2 / 0 \AA$ dan pola continuous suture (Gambar 1D). Penjahitan yang kedua dilakukan menggunakan material benang Vicryl $2 / 0 \AA$ dengan teknik matras horizontal untuk menghindari terjadi adhesi dengan organ lain. Sebelum diligasi, diberikan antibiotika Penstrep ${ }^{\circledR}$ ke dalam lumen dan setelah jahitan selesai dibuat kemudian luka insisi diperiksa kembali jika masih ada kesalahan dan kebocoran pada uterus yang diligasi.

Musculus abdominis diligasi bersamaan dengan membrane peritoneum dan bagian otot obliquus diligasi bersamaan dengan menggunakan pola horizontal mattress dalam satu lapis. Irigan diberikan dengan menggunakan penstrep yang disemprotkan secara intra abdominal sebagai langkah pencegahan kontaminasi pada rongga perut sebelum dilakukannya ligasi pada rongga perut. Kemudian kulit diligasi dengan menggunakan pola simple interrupted suture. Benang yang digunakan berupa material black Silk suture yang bersifat non-absorbable. Setelah kulit yang telah diligasi diberi salep agatis topikal dan disemprot dengan Limoxin-25® Spray (Interchemie) yang berfungsi sebagai antibiotik dan antiserangga.
Kuda diberikan antibiotik Phenylject ${ }^{\circledR} 3 \mathrm{ml}$ (2,2-4,4 $\mathrm{mg} / \mathrm{kg} 12$ jam, i.v. selama 3 hari), antibiotik Gentamicin ${ }^{\circledR}$ $\left(0,01-0,08 \mathrm{mg} / \mathrm{kg}\right.$ bb, i.v. selama 5 hari), Metronidazole ${ }^{\circledR}(25$ $\mathrm{mg} / \mathrm{kg}$ bb, i.v. selama 14 hari) dan anti inflamasi Dexamethasone ${ }^{\circledR}(2,5-5 \mathrm{mg} / \mathrm{kg}$, i.m. selama 3 hari). Luka jahitan diberikan salep agatis topikal lalu disemprot dengan Limoxin-25® spray dan dibersihkan 2 kali sehari. Kuda menunjukkan respon yang baik, makan dan minum normal, diberikan pakan rumput yang secukupnya dan diberi bran sebanyak $300 \mathrm{~g} /$ hari yang ditambahkan air sebelum diberikan.

\section{- SIMPULAN}

Kejadian kasus distokia pada kuda ras miniature lebih tinggi dibanding dengan kuda ras besar karena disebabkan fetopelvic disparity yaitu ukuran pelvis mare relatif lebih kecil dibanding ukuran fetus yang besar. Penanganan operasi caesar pada kasus distokia ini, dilakukan karena usaha penarikan manual tidak berhasil mengeluarkan fetus.

\section{- INFORMASI PENULIS}

Penulis untuk Korespondensi

*A: amrozi@apps.ipb.ac.id

Divisi Reproduksi dan Kebidanan, Departemen Klinik Reproduksi dan Patologi, Fakultas Kedokteran Hewan, Institut Pertanian Bogor, Fakultas Kedokteran. Institut Pertanian Bogor.

Jl. Agatis Kampus IPB Dramaga Bogor 16680

\section{- PUSTAKA ACUAN}

Abubakar AA, Andeshi RA, Yakubu AS, Lawal FM, Adamu U. 2014. Comparative evaluation of midventral and flank laparotomy approaches in goat. Journal of Veterinary Medicine. 2014:1-6.

Bostedt H. 1988. The use of a beta 2-mimetic agent (clenbuterol) in equine pregnancy disorders and obstetrics. Tierarztliche Praxis. 16(1):57-59.

Moges N. 2016. Etiology, incidence and economic significance of dystocia and recommendations for preventive measure and treatment to reduce the incidence of dystocia: review. Journal of Reproduction and Infertility. 7(1):24-33

Noakes DE, Parkinson DJ, England GCW. 2009. Maternal dystocia. Arthur's Veterinary Reproduction and Obstetrics. Saunders Harcourt, India $[\mathrm{IN}]$.

Purohit GN, Hannappagol SS. 2009. Dystocia and Its Management in Mares. Veterinary Obstetrics A Practical Guide. Jaypee Brothers Medical Publishers New Delhi, India [IN].

Schultz LG, Tyler JW, Moll HD, Constantinescu GM. 2008. Surgical approaches for cesarean section in cattle. The Canadian Veterinary Journal. 49(6):565-568. 